Bangladesh J. Plant Taxon. 27(2): 435-438, 2020 (December)

(C) 2020 Bangladesh Association of Plant Taxonomists

- Short communication

\title{
STATUS OF OCCURRENCE OF LIVISTONA JENKINSIANA GRIFF. IN BANGLADESH
}

\author{
Mohammad Zashim Uddin ${ }^{1}$, Md. Golam Kibria, Amit Sarker and Alokash Roy \\ Department of Botany, University of Dhaka, Dhaka 1000, Bangladesh
}

Keywords: Status of occurrence; Livistona jenkinsiana Griff.; Khadimnagar; Bangladesh.

Khadimnagar National Park is one of the reserved secondary forests, located in northern side of Sylhet Sadar Upazila, Bangladesh. Arare, fan-shaped palm species, locally called Aanor or Chatipata has primarily been located in the park. The plants have yetto bear any flowers and fruits. Leaf specimens were collected and studied in plant taxonomy laboratory. The sterile specimens were identified as Livistona jenkinsiana Griff. based on external morphological characters. Further exploration is necessary in Bangladesh to find its population status and distribution record of Livistona jenkisiana Griff.

When exploring Khadimnagar national park of Sylhet forest division in 2015 to find out the plant species of conservation worthiness the authors were encountered with a number of palms in the stream sides at the beginning of two hours trail near the forest beat office. The area is deep forest with no disturbance from humanity dominated by a good number of tree species particularly Chapalish (Artocarpus chama Buch.-Ham. ex Wall.), Champa (Michelia champaca L.), Agar (Aquilaria agallocha Roxb.), Shegun (Techtona grandis L. f.), Zybans (Bambusa vulgaris Schrad. ex Wendl.), bushy vegetations, climbers and annual herbaceous plants. Wildlife population including hanuman was encountered during the visit. Among the palm plants, one palm was identified as Pinanga gracilis which was listed earlier as red plant in our country but other one palm with fan-shaped leaves locally called Aanor or Chatipata could not be identified in the field. The authors observed carefully its vegetative growth form and took a number of images from different angles and also collected plant specimens for further study using traditional taxonomic techniques (Hyland 1972; Alexiades 1996). The specimens later were brought to plant taxonomy laboratory, Department of Botany, University of Dhaka where this was thoroughly examined and studied for all morphological properties. The unknown palm species was identified as Livistona jenkinsiana Griffith by matching of its properties with the properties given in the Flora of China (Wu et al., 2007) and Major Jenkin's palm in Thailand (Barfod et al., 2010). Identification was confirmed by discussing with Professor Anders Sanchez Barfod, Department of Biological Sciences, Aarhus University, Denmark and also authenticated by comparing with Google known images of LivistonaJenkinsianaGriff. The species has primarily been reported as rare species recorded from Bangladesh which belongs to the family Arecaceae.

Earlier the species was reported by William Griffith in 1845 from Assam and he mentioned the species may occur in Bangladesh. Very recently Barfod et al. (2010) also mentioned that the species may occur in Bangladesh territory. After W. Griffith a good number of works were done on the flora of Bangladesh including Hooker (1892), Prain (1903), Rahman and Hassan (1995), Uddin et al. (1998), Uddin and Rahman (1999), Khan and Huq (2001), Uddin et al. (2002), Uddin et al. (2005), Rafiqul et al. (2009), Tutul et al. (2009), Uddin and Hassan (2010), Arefin et al. (2010), Khondker et al. (2010) and Uddin et al. (2011, 2013). But no researchers reported this rare species from Bangladesh territory. Therefore this rare species has primarily been recognized in

\footnotetext{
${ }^{1}$ Corresponding author, E-mail: zashim01@gmail.com
} 
2015 and now reported scientifically as a rare species from Bangladesh. The status of occurrence of this rare species was confirmed with the consultation of the database of Dhaka University Salar Khan herbarium, Bangladesh National Herbarium, Chittagong University Herbarium, Jahangirnagar Uinversity Herbarium and Rajshahi University Herbarium.

Based on the field observation record and detailed studies in the plant Taxonomy Laboratory, a short description of the species is given below:

Livistona jenkinsiana Griff. Calcutta J. NatHist. 5: 334. 1845.

A tall, fan-shaped, singly growing palm, height up to 10 meter but at maturity it may reach more than 10 meter. Leaves palmate, long up to $480 \mathrm{~cm}$, petiole $340 \mathrm{~cm}$ tall, blade or lamina size across $250 \mathrm{~cm}$, split after two-third distance from the base of lamina, segment number 80 to 94 , erect at the apices, lamina externally rounded, grayish green abaxially, green adaxially, petiole 30 $\mathrm{cm}$ thick, $61 \mathrm{~cm}$ width, Petiole with two types spines along margins, decreasing in density toward distal end, arranged alternately with long $30 \mathrm{~cm}$ tall, after short, $10 \mathrm{~cm}$ tall, recurved, tip pointed, both are brown in colour (Fig. 1. A-F).
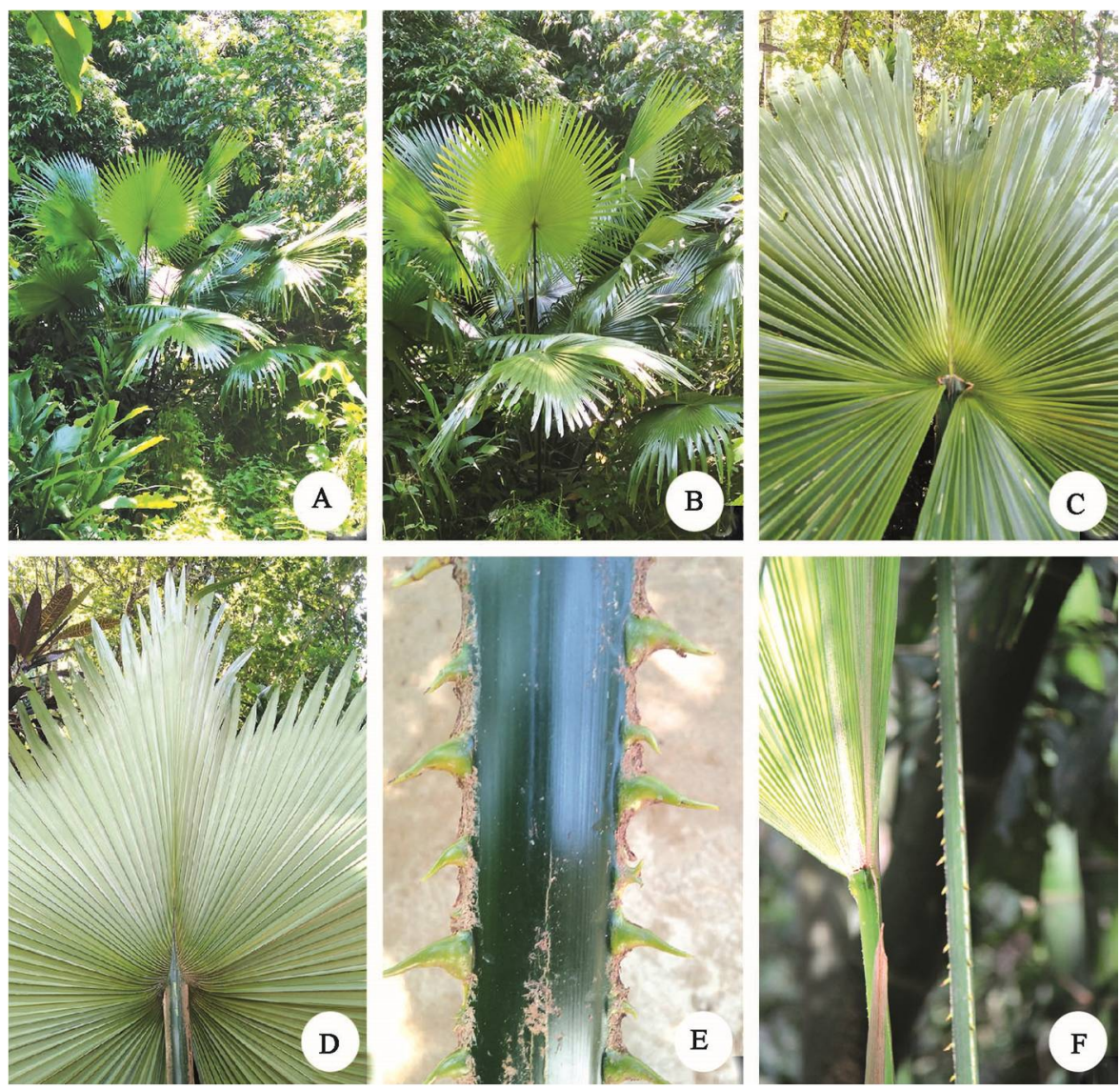

Fig. 1A-F: A Livistona jenkinsiana Griff. in natural habitat B. closed view C. adxail view of lamina, D. abaxial view E. petiole with recurved spines F. young lamina and distal end of petiole. 
Habitats: The species Livistona jenkensiana Griff. usually grows in the deep forest, the stream and channel sides and wet areas of forest and needs soil with the mixture of sand clay and silt. The habitats with high rainfall are the favour condition for the growth of this species.

Specimens examined: Sylhet Sadar Upazila, Khadimnagar National Park, near forest beat office, beginning of two hours trail in the stream bank, 1909-2020, Zashim 415 (DUSH).

In Bangladesh, the family Arecaceae is represented by 40 species (Siddiqui et al., 2007). The number of palm in Bangladesh, with addition of LivistonajenkinsianaGriff., has become 41.

Distribution: The family Arecaceae composed of nearly 3000 species (Siddiqui et al. 2007), distributed in tropical and warm-temperate regions of the world. The species Livistona jenkinsiana Griff.is distributed primarily in India, Nepal, Bhutan, China, Myanmar, Thailand and Malaysia (Wu et al., 2007, Barfod et al., 2010).

Population number of this species in khadimnagar national park is about 15-20. These are all seedling to young plants but mother trees are not present among them. According to local foresters and villagers the leaves of this plant are used in thatching purposes, hats making and rain protectors. Assumed that due to over exploitation of leaves for thatching and hats making mother trees became rare or even extinct from the area. Further exploration is necessary throughout Bangladesh, especially in hilly zones to find its population status and distribution record.

\section{Acknowledgements}

The authors acknowledge Bangladesh Forest Department for the arrangement of field trip to Khadimnagar National Park. They are also thankful to Slyhet Forest Division for local hospitality and cooperation during data collection.

\section{References}

Alexiades, M.N. (Ed.) 1996. Selected guidelines for ethno botanical research: a field manual. New York Botanical Garden, New York. pp. 99-133.

Arefin, M.K., Uddin, M..Z., Rahman, M. M. and Hassan, M.A. 2010. Angiosperm flora of Satchari National Park, Habiganj, Bangladesh. Bangladesh J. Plant Taxon. 18(2): 117-140.

Barfod, A.S, Dowe, J.L and Suksathan, P. 2010. Major Jenkin's Palm 54 (3): 109-118.

Griffith, W. 1845. The palms of British East India. Calcutta Journ. Nat. Hist. 5: 311-355.

Hooker, J.D 1892. The Flora of British India. L. Reeve \& Co., Ashford, Kent, England 6: 514 pp.

Hyland, B.P.M. 1972. A technique for collecting botanical specimens in rain forests. Flora Malesiana Bulletin 26: 2038-2040.

Khan, M.S. and Huq, M.A. 2001. The vascular flora of Chunati Wildlife Sanctuary in south Chittagong, Bangladesh.Bangladesh J. Plant Taxon. 8(1): 47-64.

Khondker, M. Hassan, M.A., Alfasane, M.A. and Shahjadee, U.F. 2010. Fruiting characteristics and biochemical composition of endangered palm species (Coryphataliera Roxb.). Bangladesh J. Plant Taxon. 17(1) 79-86.

Prain, D. 1903. Bengal Plants. Botanical Survey of India, Calcutta. 1: 359 pp.

Rafiqul, M.I., Uddin, M.Z. and Hassan, M.A. 2009. An assessment of the angiospermic flora of Ramgarh Upazila in Khagrachhari district, Bangladesh. Bangladesh J. Plant Taxon. 16(2): 115-140.

Rahman, M.O. and Hassan, M.A. 1995. Angiospermic flora of Bhawal National Park, Gazipur (Bangladesh).Bangladesh J. Plant Taxon. 2(1\&2): 47-79.

Siddiqui, K.U, Ahmed, Z.U, Hassan, M.A., Begum, Z.N.T., Khondker, M., Kabir, S.H.M., Ahmad, M., Ahmed, A.T.A. (Eds) 2007. Encyclopedia of Flora and Fauna of Bangladesh. 11. Angiosperms; Monocotyledons (Agavaceae-Najadaceae). Asiat. Soc. Bangladesh, Dhaka. 399 pp. 
Tutul, E., Uddin, M.Z., Rahman, M.O. and Hassan, M.A 2009.Angio spermic flora of Runctia Sal forest, Bangladesh.1 Liliopsida (Monocots). Bangladesh J. Plant Taxon. 16(1): 83-90.

Uddin, M.Z. and Hassan, M.A. 2010. Angiosperm diversity of Lawachara National Park (Bangladesh): a preliminary assessment. Bangladesh J. Plant Taxon. 17(1): 9-22.

Uddin, M.Z., Alam, M. F., Rahman, M.A. and Hassan, M.A. 2013. Diversity in angiosperm flora of Teknaf Wildlife Sanctuary, Bangladesh. Bangladesh J. Plant Taxon. 20(2): 145-162.

Uddin, M.Z., Alam, M..F., Rahman, A.S.M. and Hassan, M.A. 2011. Plant biodiversity of Fashiakhali wildlife sanctuary, Bangladesh. Proceedings: First Bangladesh Forestry Congress. pp. 129-141.

Uddin, M.Z., Hassan, M.A. and Hosen, M.M. 2005. A checklist of angiospermic flora of Lalmai Hills, Comilla, Bangladesh.Bangladesh J. Plant Taxon. 12(2): 85-96.

Uddin, M.Z., Hassan, M.A. and Khan, M.S. 2002. An annotated checklist of angiospermic flora of RemaKalenga wildlife sanctuary (Habiganj) in Bangladesh-1. Liliopsida (Monocots). Bangladesh J. Plant Taxon. 9(2): 57-66.

Uddin, S.B. and Rahman, M.A. 1999. Angiospermic flora of Himchari National Park, Cox's Bazar, Bangladesh. J. Plant Taxon. 6(1): 31-68.

Uddin, S.N., Khan, M.S., Hassan, M.A. and Alam, M.K. 1998. An annotated checklist of angiospermic flora of Sita Pahar at Kaptai in Bangladesh. Bangladesh J. Plant Taxon. 5(1): 13-46.

Wu, Z.Y., Raven, P.H. and Hong, D.H. (eds). 2007. Flora of China 23 (Arecaceae): 147. Science Press, Beijing, and Missouri Botanical Garden Press, St. Louis. 